\title{
PEMBELAJARAN DEBAT KOMPETITIF SEBAGAI PENGEMBANGAN KEMAMPUAN BERBICARA SISWA KELAS X SMA NEGERI 20 MEDAN \\ TAHUN PEMBELAJARAN 2016/2017
}

\author{
ARTIKEL \\ Diajukan untuk Memenuhi Sebagian Syarat \\ Memperoleh Gelar Sarjana Pendidikan
}

Oleh

RUMANTI NAINGGOLAN

NIM 2132111017

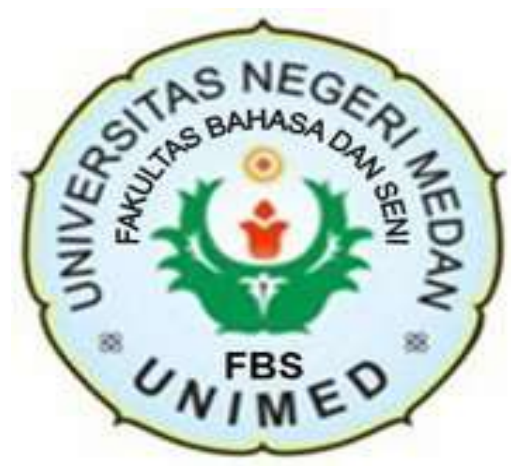

JURUSAN BAHASA DAN SASTRA INDONESIA

FAKULTAS BAHASA DAN SENI

UNIVERSITAS NEGERI MEDAN

2017 
ARTIKE.

\section{PEMBELAJARAN DEBAT KOMPETTTIF SEBAGAI \\ PENGEMBANGAN KEMAMPUAN BERBICARA \\ SISWA KELAS X SMA NEGERI 20 MEDAN}

TAHUN PEMBELAJARAN 2016/2017

Oleh

Rumanti Nainggolan

NIM 2132111017

Dosen Pembimbing Skripsi

Dn. Basyaruddin, M.Pd.

Telah Diverifikasi dan Dinyatakun Memenuhi Syarat untuk Diunegah pada Jurnat Online

Editor,

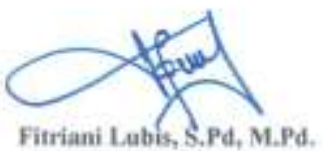

NIP 197708312008122001
Medan, Agustus 2017 Meayetujui :

Dosen Pembimbing Skripsi,

Dr. Basyaniddin, M.Pd.

NIP 195809041986011001 


\title{
$a *$
}

\section{PEMBELAJARAN DEBAT KOMPETITIF SEBAGAI \\ PENGEMBANGAN KEMAMPUAN BERBICARA \\ SISWA KELAS X SMA NEGERI 20 MEDAN \\ TAHUN PEMBELAJARAN 2016/2017}

\author{
Oleh \\ Rumanti Nainggolan \\ Rumantynainggolan@gmail.com \\ Drs. Basyaruddin, M.Pd.
}

Penelitian ini bertujuan untuk mengetahui pengaruh pembelajaran debat kompetitif terhadap kemampuan berbicara siswa kelas $\mathrm{X}$ SMA Negeri 20 Medan tahun pembelajaran 2016/2017. Dari 182 siswa, ditetapkan 38 siswa orang sebagai sampel secara random. Metode yang digunakan dalam penelitian ini adalah metode eksperimen one-group pre-test post-test design. Instrumen yang digunakan untuk menjaring data berbentuk penilaian unjuk kerja/skala penilaian. Pengujian hipotesis dilakukan dengan menggunakan uji " $t$ ". Data yang diperoleh menunjukkan bahwa kemampuan siswa berbicara sebelum pembelajaran debat kompetitif masuk dalam kategori kurang baik dengan nilai rata-rata 57,38 sedangkan setelah diadakan pembelajaran debat kompetitif termasuk dalam kategori baik dengan nilai rata-rata 74,33. Selanjutnya pengujian hipotesis menunjukkan $t_{\text {hitung }}>t_{\text {tabel }}$ yaitu 9,74 $>2,03$ pada taraf signifikan $\alpha$ $=0,05$. Dengan demikian, telah terbukti bahwa hipotesis nihil $\left(\mathrm{H}_{\mathrm{o}}\right)$ ditolak dan hipotesis alternatif $\left(\mathrm{H}_{\mathrm{a}}\right)$ diterima .

Kata Kunci: Kemampuan Berbicara, SMA Negeri 20 Medan

\section{PENDAHULUAN}

Manusia adalah makhluk sosial yang selalu berkomunikasi dengan orang lain sebagai wujud interaksi. Interaksi tersebut selalu didukung oleh alat komunikasi vital yang mereka miliki bersama, yaitu bahasa. Bahasa merupakan salah satu faktor hakiki yang membedakan manusia dari makhluk lainnya. Oleh karena itu, pembelajaran bahasa Indonesia diarahkan kepada kemampuan siswa berkomunikasi dan fungsi utama sastra sebagai penghalus budi, peningkatan rasa kemanusiaan, kepedulian sosial, penumbuhan apresiasi budaya, serta penyalur gagasan, imajinasi, dan ekspresi.

Berbicara merupakan salah satu aspek keterampilan berbahasa yang sangat penting peranannya untuk menciptakan manusia yang cerdas, kritis, dan kreatif. Sehingga keterampilan berbicara perlu dikuasai dengan baik. Kemampuan ini merupakan suatu indikator terpenting bagi keberhasilan siswa terutama dalam 
belajar bahasa Indonesia. Dengan penguasaan keterampilan berbicara yang baik, siswa dapat mengomunikasikan ide-ide mereka, baik di sekolah maupun diluar sekolah.

Menurut Tarigan (2015:2) bahwa "Keterampilan berbahasa hanya dapat diperoleh dan dikuasai dengan praktek dan banyak latihan." Keterampilan berbicara seseorang tidak datang secara otomatis, namun harus berlatih dan belajar secara intensif. Keterampilan berbicara harus dilatih melalui proses belajar dan latihan secara berkesinambungan dan sistematis agar dapat memperlancar seseorang dalam berkomunikasi. Apabila kita tidak pernah berlatih mengorganisir ide, pikiran atau perasaan dalam bentuk kata-kata secara lisan maka keterampilan berbahasa lisan tidak dikuasai.

Pembelajaran bahasa Indonesia harus mendapat perhatian agar siswa mampu berkomunikasi dengan baik. Peserta didik sebagai makhluk sosial harus terampil berbahasa dan mampu mengekspresikan dirinya dengan menggunakan bahasa. Namun berdasarkan wawancara penulis dengan beberapa siswa kelas $\mathrm{X}$ SMA Negeri 20 Medan, pembelajaran bahasa Indonesia merupakan pelajaran yang kurang disenangi dan sangat membosankan, khususnya berbicara. Karena itu dalam interaksi belajar mengajar bahasa Indonesia, seorang guru harus memperhatikan faktor-faktor yang menyangkut siswa diantaranya kecerdasan, minat, dan suasana pembelajaran. Menurut Lamajau, E (2013:4) bahwa "Pembelajaran aktif ditandai oleh dua faktor sebagai berikut: 1) Adanya interaksi antara seluruh komponen dalam proses pembelajaran terutama antara guru dan Siswa. 2) Berfungsi secara optimal seluruh sense siswa yang meliputi indera, emosi, karsa, dan nalar."

Masalah tersebut juga didukung oleh hasil wawancara penulis dengan guru mata pelajaran bahasa Indonesia kelas X yaitu ibu Raudah. Siswa masih mengalami kesulitan untuk menyampaikan gagasan, pikiran, pertanyaan, mendukung atau menentang suatu pernyataan dan sebagainya dengan menggunakan ragam bahasa lisan dengan baik dan benar. Hal tersebut disebabkan oleh beberapa faktor, diantaranya siswa malu dan tidak memiliki rasa percaya diri untuk menyampaikan gagasan atau pendapat. Faktor lainnya adalah kemampuan siswa berbicara dari segi kebahasaan (ketepatan ucapan, penempatan tekanan, 
nada, durasi, pilihan kata, dan ketepatan sasaran pembicaraan) dan nonkebahasaan (Sikap, pandangan, kesediaan menghargai pendapat, gerak-gerik dan mimik, suara, kelancaran, penguasaan topik) masih rendah. Perbendaharaan kosa kata yang kurang, menyebabkan siswa ragu untuk berbicara sehingga mereka mengucapkan kalimat secara berulang-ulang. Ketika berbicara masih banyak siswa yang ekspresinya tidak sesuai dengan hal yang dibicarakan, gerak-gerik yang kaku, suara yang tidak jelas dan tidak menguasai bahan.

Masalah di atas diperkuat oleh penelitian Setiawardani (2013) dalam jurnalnya yang berjudul "Penggunaan Media Audio-Visual Video pada Pembelajaran Bahasa Indonesia untuk Meningkatkan Keterampilan Berbicara” Mengatakan bahwa salah satu penyebab rendahnya kemampuan siswa berbicara adalah kurangnya partisipasi siswa dalam pembelajaran di kelas. Siswa tidak menggunakan kesempatan-kesempatan yang diberikan oleh guru untuk bertanya mengenai materi pelajaran yang belum dimengerti.

Sesuai dengan Standar Kompetensi Lulusan pada kurikulum 2013 revisi, sasaran pembelajaran mencakup tiga ranah yaitu, pengembangan ranah sikap, pengetahuan, dan keterampilan. Pengembangan ranah keterampilan diperoleh melalui aktivitas mengamati, menanya, mencoba, menalar, menyaji, dan mencipta. Untuk mengetahui sejauh mana kemampuan siswa dalam kemampuan berbicara perlu adanya pembelajaran yang efektif dalam pembelajaran debat kompetitif yang merupakan salah satu materi pelajaran yang terdapat dalam kurikulum 2013 revisi SMA/SMK/MA/MAK kelas X.

Ismawati Esti (2012:20-21) mengatakan, "Debat pada hakikatnya adalah saling adu argumentasi antar pribadi atau antar kelompok manusia, dengan tujuan mencapai kemenangan untuk satu pihak." Debat kompetitif adalah debat yang biasa dilakukan di tingkat sekolah dan universitas. Dalam hal ini debat dilakukan sebagai pertandingan dengan aturan yang jelas dan ketat antara dua pihak yang masing-masing mendukung dan menentang sebuah pernyataan.

Pembelajaran debat sangat mendukung pengembangaan kemampuan berbicara peserta didik dalam situasi formal. Dalam pembelajaran ini siswa dilatih bagaimana mengeluarkan pendapat/pemikirannya dan bagaimana mempertahankan pendapatnya dengan alasan-alasan yang logis dan dapat 
dipertanggungjawabkan. Siswa belajar untuk menghargai adanya perbedaan bukan untuk saling bermusuhan.

Hendricus (1991:128) mengatakan, "Debat memiliki karakter pembinaan yang tinggi, sebab lewat debat siswa dapat dilatih dan dibina untuk menyiapkan bahan diskusi secara teliti, tepat sasaran, mempertenggangkan pendengar yang bakal ditarik untuk menerima kebijaksanaan kelompok." Debat dapat membina peserta untuk berbicara singkat, padat dan mengesankan. Dalam debat setiap pribadi atau kelompok mencoba menjatuhkan lawannya, supaya pihaknya berada pada posisi yang benar. Para peserta sungguh-sungguh saling membantah lewat argumentasi dan bukan sekedar mau memperoleh pengertian dan pengetahuan baru. Oleh karena itu keterampilan berbicara harus benar-benar dikuasai.

Pencapaian tujuan belajar tercermin dari kemampuan belajar siswa yang dituangkan dalam bentuk nilai dan keterampilan yang dimiliki oleh siswa dalam mata pelajaran yang bersangkutan. Melalui kemampuan yang diraih oleh siswa kita dapat mengetahui kadar penguasaan kompetensi dari mata pelajaran yang diberikan.

Berdasarkan latar belakang di atas, muncul ketertarikan penulis untuk mengadakan penelitian dengan judul "Pembelajaran Debat Kompetitif sebagai Pengembangan Kemampuan Berbicara Siswa Kelas X SMA Negeri 20 Medan Tahun Pembelajaran 2016/2017".

\section{METODE PENELITIAN}

Metode penelitian adalah cara yang digunakan oleh peneliti dalam mengumpulkan data penelitiannya. Sesuai dengan tujuan penelitian ini untuk mengetahui pengembangan kemampuan berbicara siswa dengan pembelajaran debat kompetitif siswa kelas X SMA Negeri 20 Medan, maka metode yang digunakan oleh peneliti adalah metode eksperimen. Menurut Sugiyono (2016:107) "Metode eksperimen adalah metode penelitian yang digunakan untuk mencari pengaruh perlakuan tertentu terhadap yang lain dalam kondisi yang terkendalikan." Untuk melihat akibat dari perlakuan tersebut peneliti menggunakan metode One-Grup Pretest-Posttest design. Penelitian dilakukan hanya pada satu kelas, yakni kelas eksperimen dengan sampel berjumlah 38 siswa. 
Sugiyono (2009:305) mengatakan "untuk memperoleh data dalam penelitian, instrumennya dapat berupa tes, pedoman wawancara (interview), pedoman observasi, dan kuesioner." Arikunto (2010:203) menyatakan, "Instrumen penelitian adalah alat atau fasilitas yang digunakan oleh peneliti dalam mengumpulkan data agar pekerjaannya lebih mudah dan hasilnya lebih baik, dalam arti lebih cermat, lengkap, dan sistematis sehingga lebih mudah diolah."

Dalam penelitian ini, peneliti memperoleh data menggunakan alat pengumpulan data berbentuk penilaian unjuk kerja. Penilaian unjuk kerja merupakan penilaian yang dilakukan dengan mengamati kegiatan peserta didik dalam melakukan sesuatu dan untuk mengamati unjuk kerja peserta didik dapat menggunakan instrument skala penilaian.

\section{HASIL PENELITIAN DAN PEMBAHASAN}

A. Hasil Penelitian

1. Data Kemampuan Berbicara Siswa Sebelum Pembelajaran Debat Kompetitif

Nilai rata-rata sebelum pembelajaran debat kompetitif (pre-test) sebesar 57,38 dengan nilai tertinggi adalah 75 dan nilai terendah adalah 44,44. Setelah dikategorikan, kemampuan berbicara siswa sebelum pembelajaran debat kompetitif terbagi atas tiga kategori, yaitu, kategori baik sebanyak 3 orang atau $7,89 \%$, kategori cukup sebanyak 20 orang atau 52,63\%, dan kategori kurang sebanyak 15 orang atau 39,48\%. Kategori yang paling banyak adalah kategori cukup.

\section{Data Kemampuan Berbicara Siswa Setelah Pembelajaran debat Kompetitif}

Nilai rata-rata yang diperoleh setelah pembelajaran debat kompetitif (posttest) sebesar 74,33 dengan nilai tertinggi adalah 91,66 dan nilai terendah adalah 61,11. Setelah dikategorikan, kemampuan berbicara siswa setelah pembelajaran debat kompetitif terbagi atas tiga kategori, yaitu, kategori sangat baik sebanyak 3 orang atau 7,89\%, kategori baik sebanyak 27 orang atau $71,06 \%$, dan kategori cukup sebanyak 8 orang atau $21,05 \%$. Kategori paling banyak adaklah kategori baik.

3. Pengaruh Pembelajaran Debat Kompetitif terhadap Kemampuan Berbicara Siswa Kelas X SMA Negeri 20 Medan Tahun Pembelajaran 2016/2017 
Setelah dilakukan pengolahan data, diperoleh nilai rata-rata sebelum pembelajaran debat kompetitif sebesar 57,38 yang tergolong kategori cukup. Sedangkan perhitungan data kemampuan siswa setelah pembelajaran debat kompetitif diperoleh rata-rata 74,33 dan tergolong pada kategori baik. Dari data tersebut dapat diketahui bahwa pembelajaran debat kompetitif berpengaruh terhadap kemampuan berbicara siswa karena adanya perbedaan nilai rata-rata yang diperoleh siswa.

\section{B. Pembahasan Hasil Penelitian}

1. Kemampuan Berbicara Sebelum Pembelajaran Debat Kompetitif Siswa Kelas X SMA Negeri 20 Medan Tahun Pembelajaran 2016/2017

Sebelum diterapkannya pembelajaran debat kompetitif kemampuan siswa berada pada kategori kurang dengan nilai rata-rata 57,38. Kemampuan berbicara siswa berada di bawah nilai KKM yang sudah ditentukan yaitu 70. Hal ini dapat dilihat dari persentase nilai siswa yang berada pada kategori baik sebanyak 3 orang $(7,89 \%)$, kategori cukup sebanyak 20 orang (52,63\%), dan kategori kurang sebanyak 15 orang $(39,48 \%)$.

Persentase kemampuan siswa di atas menunjukkan bahwa siswa belum mampu memenuhi kompetensi yang diharapkan. Kemampuan siswa dalam berbicara (menyampaikan gagasan) harus mendapatkan perhatian dengan baik.

Rendahnya kemampuan berbicara siswa disebabkan kurangnya rasa percaya diri siswa untuk menyampaikan gagasan atau pendapat. Ketika guru menyuruh siswa berbicara, masih banyak siswa yang malu bahkan ada yang hanya diam. Rendahnya kreativitas guru dalam pembelajaran bahasa Indonesia, khususnya keterampilan berbicara merupakan salah satu penyebab rendahnya hasil belajar siswa. Guru kurang mengaktifkan siswa untuk membiasakan melatih kemampuan berbicaranya.

\section{Kemampuan Berbicara Setelah Pembelajaran Debat Kompetitif Siswa Kelas X SMA Negeri 20 Medan Tahun Pembelajaran 2016/2017}

Setelah diterapkan pembelajaran debat kompetitif kemampuan siswa berada pada kategori baik dengan nilai rata-rata 74,33. Kemampuan berbicara siswa sudah mencapai nilai KKM yang sudah ditentukan yaitu 70. Hal ini dapat dilihat dari persentase nilai siswa yang berada pada kategori sangat baik sebanyak 3 orang atau 7,89\%, kategori baik sebanyak 27 orang atau 71,06\%, dan kategori 
cukup sebanyak 8 orang atau $21,05 \%$. Persentase kemampuan siswa tersebut menunjukkan bahwa siswa sudah mampu memenuhi kompetensi yang diharapkan. Kemampuan siswa dalam berbicara (menyampaikan gagasan) sudah mengalami perkembangan

Pembelajaran debat kompetitif membantu siswa untuk berbicara karena dalam pembelajaran ini siswa mencoba untuk menjatuhkan lawan bicaranya, supaya pihaknya berada pada posisi yang benar. Peserta didik berusaha menjadi yang terbaik dengan mempertahankan gagasan dan saling membantah lewat argumentasi. Pembelajaran debat kompetitif ini efektif digunakan guru dalam proses pembelajaran kemampuan berbicara siswa. Melalui penerapan pembelajaran debat kompetitif, siswa lebih aktif dan berani untuk menyampaikan argumentasinya.

\section{Pengaruh Pembelajaran Debat Kompetitif terhadap Kemampuan Berbicara Siswa Kelas X SMA Negeri 20 Medan Tahun Pembelajaran 2016/2017}

Pembelajaran debat kompetitif merupakan pembelajaran yang dapat mengembangkan kemampuan berbicara (menuangkan ide/gagasan secara lisan) siswa dan mampu membangkitkan semangat siswa dalam belajar. Hal ini dapat dilihat dari hasil penelitian yang menunjukkan nilai rata-rata kemampuan berbicara sesudah melaksanakan pembelajaran debat kompetitif lebih tinggi yakni sebesar 74,33 (kategori baik), dibandingkan nilai rata-rata kemampuan berbicara sebelum pembelajaran debat kompetitif, yakni sebesar 57,38 (kategori kurang). Pengujian hipotesis telah membuktikan bahwa hipotesis nihil $\left(\mathrm{H}_{\mathrm{o}}\right)$ ditolak dan hipotesis alternatif $\left(\mathrm{H}_{\mathrm{a}}\right)$ diterima, karena $\mathrm{t}_{0}$ yang diperoleh lebih besar dari $\mathrm{t}_{\text {tabel }}$ yaitu $9,74>2,03$. Hal ini membuktikan bahwa pembelajaran debat kompetitif memiliki pengaruh dalam mengembangkan/meningkatkan kemampuan berbicara siswa kelas X SMA Negeri 20 Medan tahun pembelajaran 2016/2017.

\section{PENUTUP}

Berdasarkan hasil analisis data penelitian dan pengujian hipotesis dapat disimpulkan bahwa kemampuan berbicara siswa kelas X SMA Negeri 20 Medan tahun pembelajaran 2016/2017 sebelum pembelajaran debat kompetitif tergolong pada kategori kurang baik dengan nilai rata-rata 57,38. 
Kemampuan berbicara siswa kelas X SMA Negeri 20 Medan tahun pembelajaran 2016/2017 setelah pembelajaran debat kompetitif tergolong pada kategori baik dengan nilai rata-rata 74,33.

Pembelajaran debat kompetitif dapat mengembangkan kemampuan berbicara siswa kelas X SMA Negeri 20 Medan tahun pembelajaran 2016/2017. Hal tersebut dapat dilihat dari perbandingan hasil test kemampuan berbicara setelah pembelajaran debat kompetitif (Post-test) yakni sebesar 74,33 (kategori baik), dan hasil test kemampuan berbicara sebelum pembelajaran debat kompetitif (Pre-test) yakni sebesar 57,38 (kategori cukup). Berdasarkan pengujian hipotesis, $\mathrm{t}_{0}$ yang diperoleh lebih besar dari $\mathrm{t}_{\text {tabel }}$ yaitu 9,74 > 2,03 maka hipotesis nihil $\left(\mathrm{H}_{\mathrm{o}}\right)$ ditolak dan hipotesis alternatif $\left(\mathrm{H}_{\mathrm{a}}\right)$ diterima.

\section{DAFTAR PUSTAKA}

Arikunto, Suharsimi. 2009. Prosedur Penelitian Suatu Pendekatan Praktik. Jakarta: Rineka Cipta

-2010. Prosedur Penelitian Suatu Pendekatan Praktik. Jakarta: Rineka Cipta

Hendricus. 1991. "RETORIKA (Tampil Berpidato, Berdiskusi, Berargumen, Bernegosiasi)”. Yogyakarta: Kanisius

Ismawati, Esti. 2012. Bahasa Indonesia untuk Penulisan Karya Ilmiah. Yogyakarta: Omba

Sugiyono. 2009. Metode Penelitian Pendidikan (Pendekatan Kuantitatif, Kualitatif, dan $R \& D)$ ). Bandung: Alfabeta

2016. Metode Penelitian Pendidikan (Pendekatan Kuantitatif, Kualitatif, dan $R \& D)$ ). Bandung: Alfabeta

Tarigan. 2015. Berbicara sebagai suatu Keterampilan Berbicara. Bandung: Angkasa

Setiawardani, W. 2013. "Penggunaan Media Audio-Visual Video Pada Pembelajaran Bahasa Indonesia Untuk Meningkatkan Keterampilan Berbicara”: Antologi PGSD Bumi Siliwangi.1 (3), 1-9 